\title{
Influencia que sobre las propiedades físico-mecánicas de los morteros de cemento portland tiene la adición de colofonia y tanino
}

\author{
Influence on the physical-mechanical properties \\ of portland-cement mortar, have admixtures \\ of colophony and tannin
}

M. FERNÁNDEZ CÁNOVAS, Dr. Ing. de Construcción; N. HURTADO SELVA, Dr. C. Quimicas; G. M. KAWICHE, Ing. Civil

E. T. S. Ingenieros de Caminos. Madrid/ESPAÑA

\section{RESUMEN}

Se ha empleado la colofonia como aditivo en el mortero de cemento portland con el fin de observar su influencia sobre el contenido de aire, absorción de agua, capacidad adhesiva y propiedades mecánicas. Los resultados obtenidos han puesto de manifiesto que la colofonia actúa como aireante, aumenta la impermeabilidad y mejora la adherencia de la pasta al árido. Asimismo, la adición de tanino y cera montana a la colofonia tiene el efecto de reducir la formación de espuma y mejorar también la impermeabilidad del mortero.

\begin{abstract}
The colophony has been used as an admixture in the portland cement mortar with the intention to observe its influence on the air content, water absorption, adhesive capacity and mechanical properties. The results obtained have shown that, the colophony acts as air entrainment. reduces the permeability and improves the adhesion between the past and aggregates. Likewise, the addition of tannin and montan wax to the colophony has the efect of reducing the formation of foam and improves the impermeability of the mortar.
\end{abstract}

\section{INTRODUCCIÓN}

El empleo de polímeros, ya sean de origen inorgánico u orgánico, en el hormigón con fines plastificantes y aireantes es muy antiguo. Según diversos autores, el uso de polímeros, particularmente los naturales, es muy anterior a nuestra era. En tiempos remotos se emplearon aditivos que actuaban como adhesivos o colas tales como cucia, goma arábiga, cola de pezuñas de animales, sangre de hipopótamo, jugo de leche de higo mezclado con yema de huevo (1). Asimismo, se empleaban aditivos poliméricos tales como la queratina, caseína, manteca de cerdo, leche cuajada, etc. con la finalidad de regular el fraguado y endurecimiento de determinados materiales de construcción, así como para aumentar su adherencia e impermeabilidad (2).

\section{INTRODUCTION}

The use of polymers, whether be of inorganic or organic origen on the concrete as plasticizers and air-entraining agent is very antique. According to various authors, the use of polymers, particularly de natural ones is far foregoing in our era. In those remote days the used admixtures which acted like adhesives or glues such as arabic gum, animal glue, hipopotamus 'blood, figs' milky joice mixed with egg york, etc. (1). Similarly they used polymeric admixturres such as keratin, casein, pigs'fat (from the abdomen), coagulated milk, etc. with an intention of regulating the setting and hardening of some determined construction materials, as well as to increase adhesion and impermeability (2). 
Por otra parte, Bankart (3) da cuenta del empleo de tanino y cola en el estuco, mortero utilizado en la Iglesia Bautista de Constantinopla. Asimismo, Chandra y Aavick $(4,13)$ añadieron "Black gram", gluteína de harina caseína y proteína de leche para aumentar la adherencia de los morteros, así como su impermeabilidad y resistencia.

Todos estos polímeros contienen restos de aminoácidos, dispuestos en segmentos y formados por largas cadenas que contienen enlaces peptídicos
On the other hand, Bankart (3) informs of the use of tannin and glutinous substances in the fine plaster used for plastering the walls of the Baptist church in Constantinople. Similarly, Chandra and Aavick (4) added "Black gram", gluten from flour, casein from milk to increase the mortar adhesion, as well as its impermeability and resistance.

All these polymers contains the rests of aminoacids arranged in segments which are formed by large chains that contains peptide links
Los segmentos pueden tener carácter polar o apolar, introduciendo en este caso propiedades hidrófobas al mortero.

El trabajo que se presenta en este artículo y que tiene por objeto estudiar la influencia de la adición de colofonia y tanino sobre las propiedades de los morteros de cemento forma parte de la Tesis que con el título "Durabilidad de morteros reforzados con fibras de sisal" está desarrollando en la Cátedra de Materiales de Construcción de la E.T.S. de Ingenieros de Caminos, Canales y Puertos de Madrid el Ingeniero Civil G. Kawiche.

La colofonia es un compuesto cuya importancia se puso ya de manifiesto hace muchos años en una colección de artículos publicados por la American Society for Testing Materials (ASTM) y cuya aplicación se extiende a las industrias de barnices, aislamientos eléctricos, adhesivos, recubrimientos de protección en construcción, etc.

Además la colofonia presenta las ventajas de ser un producto natural, renovable y económico.

En el trabajo de tesis doctoral, mencionado con anterioridad, se ha empleado la colofonia con gran éxito como agente impregnante de las fibras de sisal incorporadas en el refuerzo de morteros de cemento portland. La colofonia, residuo de la destilación de resinas de muchas coníferas, está compuesta fundamentalmente por ácidos resínicos y una pequeña fracción, aproximadamente un $10 \%$ de otros compuestos no ácidos. Los ácidos resínicos son ácidos monocarboxílicos de alquil-hidrofenantrenos, en tanto que la
The segments can have polar or non polar character, they in introduce, in this case hydrofobic properties to the mortar.

The work presented in this article and which has the objetive of studying the influence of colophony and tannin admixture on the properties of cement mortars form part of a thesis entiled "Durabilidad de Morteros reforzados con fibras de sisal" which is being carried out in the Department of Construction and Building Materials of Escuela Técnica Superior de Ingenieros de Caminos, Canales y Puertos de Madrid by the Civil Engineer G. $M$. Kawiche.

A colophony is a composite whose importance has already been manifested many years ago in some collections of articles published by the American Society of Testing Materials (ASTM) and whose application extends in the industries of varnish, electrical insulations, adhesives, protection cover in the construction etc.

Moreover, the colophony has the advantage of been a natural product, renewable and economic.

In the mentioned doctorate thesis work the colophony has been used with great success; as an impregnating agent on the sisal fibres incorporated in the portland cement mortar as reinforcement. The colophony is a residuo of resin destilation of many coniferous; it is composed mainly of resinic acids and a small fraction of other non-acidic composites which approximate $10 \%$. 
fracción neutra está compuesta aproximadamente por un $60 \%$ de ésteres de ácidos resínicos y grasos y constituye la fracción saponificable de la colofonia. Consecuentemente, su hidrólisis alcalina por hidróxido sódico o cálcico produce jabones cuya parte hidrofóbica al actuar como repelente del agua disminuye la absorción de ésta en el mortero y asimismo produce una oclusión del aire disminuyendo la porosidad abierta del mortero.

Por otra parte, son sobradamente conocidas las propiedades de resistencia al agua y vapor de agua, la tenacidad, la resistencia a tracción, etc. de la cera montana, lo que ha determinado su empleo en el trabajo de la referida tesis doctoral con los mismos fines ya indicados para la colofonia. En cuanto a los taninos también presentan propiedades hidrofóbicas como las ceras y, como ya se mencionó al principio de este apartado, su uso en la vertiente de la mejora de las propiedades de los morteros es conocido desde muy antiguo. Por ello, sabidas las propiedades hidrofóbicas de las ceras y los taninos, se realizaron ensayos en los que se utilizaron conjuntamente con la colofonia.

Las resistencias mecánicas, absorción de agua y porosidad de los morteros de cemento portland en los que se utilizaban estas adiciones se compararon con las de morteros de control, es decir, sin adición de ningún tipo.

\section{MATERIALES EMPLEADOS Y METODO}

Los morteros de cemento portland ensayados estaban compuestos de los siguientes materiales:

\section{Cemento.-Cemento Portland con adición de puzolana tipo II-Z/35 que cumple la norma española UNE 80301.}

Arena.-Arena silicea de río lavada, con tamaño máximo de $2 \mathrm{~mm}$.

Agua.-Agua potable.

Adiciones.-Colofonia molida (que se incorpora al mortero en la fase de mezcla del cemento con la arena).

- Tanino vegetal en forma de polvo y soluble en agua.

- Cera montana, en forma de microesferas.

Se han ensayado dos morteros cuya composición ha sido: 1 : 2 ó $1: 1,5$ (cemento: arena, en peso).
The resinic acids are mono-caboxylic acids of alquil-hydrofenenthrens such that the neutral fraccion is composed of approximately $60 \%$ of ether resinic acids and fats which form the saponification fraction of the colohony. Consequently, its alkaline hydrolysis by soaps of sodium and calcium hydroxides whose hydrofobic part acts as a water repelent reduces the mortar absorption and, at the same time, produces air oclution which reduces the open porosity of the mortar.

On the other hand; it is far well known the properties of Montan wax in the resistance to water and water vapour, the tenacity, tensile strength etc., which has determined its use in the refered doctorate thesis in the same lines as those explained in the case of colophony. Concerning tannins, these presents similar hydrofobic properties as the waxes and as already mentioned at the first its use in the improvement of the cement mortars properties is well known from remote days. For that matter knowing the hydrofobic properties of the waxes and the the tannins test samples were made in combination with colophony.

The mechanical resistances, water absorption and porosity for portland cement mortar with these admixtures were compared with the control mortar; that is to say mortar without any admixture.

\section{MATERIALS USED AND METHODS}

The portland cement mortars tested were composed of the following materials:

\section{Cement.-Portland cement with pozzolanic addition type $/ /-\mathrm{Z} / 35$ which complies with the Spanish Norm UNE 80301.}

Sand.-Siliceous sand from river of maximun size $2 \mathrm{~mm}$ washed.

Water.-Potable water.

Admixtures.-Grounded colophony (which was incorporated in the mortar during the mixing of cement and sand fase).

- Vegetable tannin in powder form and soluble in water.

- Montan wax in microspheres'form.

Two mortar mixed proportions were tested; their proportions were $1: 1.5$ and $1: 2$ (cement : sand) by weight. 
A estos morteros se añadieron las adiciones mencionadas en diferentes proporciones y en ellos se emplearon distintas relaciones agua : cemento. Con estos morteros se fabricaron series de seis probetas prismáticas de $40 \times 40 \times 160 \mathrm{~mm}$, determinándose sus resistencias mecánicas a flexotracción y compresión, y probetas de $3 \times 40 \times 40 \mathrm{~mm}$ para determinar la absorción al agua y la porosidad relativa.

De las seis probetas de cada mortero, tres se sometieron cuando tenían la edad de 14 días a un tratamiento térmico consistente en un desecado en ambiente de laboratorio durante 24 horas, seguido de un calentamiento en estufa realizado en dos etapas, una primera de 3 horas a $40^{\circ} \mathrm{C}$ y una segunda de 3 horas a $80^{\circ} \mathrm{C}$, seguida de una bajada de temperatura, manteniendo $40^{\circ} \mathrm{C}$ durante 3 horas y enfriando posteriormente a temperatura ambiente.
To these mortars different proportions of mentioned additives were added varying the water/cement ratios. Various series of prismatic cubes of $40 \times 40 \times 160 \mathrm{~mm}$ were fabricated using these mortars for determining their mechanical resistance to flexion and compresion, and cubes of $3 \times 40 \times 40 \mathrm{~mm}$ for determining the water absorption and the relative porosity.

Of the six (6) cubes of each mortar three were subjected to heat treatment at the age of 14 days, the heat treatment consisted in drying 24 hours at laboratory temperature, followed by heating on a heating chamber which were carried out in two stages, the first 3 hours at $40^{\circ} \mathrm{C}$ and the second 3 hours at $80^{\circ} \mathrm{C}$ followed by lowering the temperature, maintaining it at $40^{\circ} \mathrm{C}$ for 3 hours and latter to ambient temperature.

Cuadro I Table 1

Mortero $1: 1,5$ (Mortar $1: 1,5$ )

\begin{tabular}{|c|c|c|c|c|c|c|c|}
\hline \multirow{2}{*}{$\begin{array}{l}\text { Idanil- } \\
\text { Thación } \\
\text { (identi- } \\
\text { fication) }\end{array}$} & \multirow{2}{*}{$\begin{array}{l}\text { Tlpo de } \\
\text { adición } \\
\text { (Type of } \\
\text { addition) }\end{array}$} & \multirow{2}{*}{$\begin{array}{c}\text { Adición } \\
\% \\
\text { (Addi- } \\
\text { tion \%) }\end{array}$} & \multirow{2}{*}{$\begin{array}{c}\text { Relación } \\
\text { agua/ce- } \\
\text { mento } \\
\text { (Water/ } \\
\text { cement } \\
\text { ratio) }\end{array}$} & \multicolumn{2}{|c|}{$\begin{array}{c}\text { Resistencias mecánicas } \\
\text { (Mechanical resistences) } \\
\left(\mathbf{k g f} / \mathrm{cm}^{2}\right)\end{array}$} & \multirow{2}{*}{$\begin{array}{c}\text { Porosidad } \\
\text { relativa } \\
\% \\
\text { (Relative } \\
\text { porosity } \\
\% \text { ) }\end{array}$} & \multirow{2}{*}{$\begin{array}{c}\text { Absorción } \\
\% \\
\text { (Absor- } \\
\text { tion \%) }\end{array}$} \\
\hline & & & & $\begin{array}{c}\text { Flexotracción } \\
\text { (Flexion) }\end{array}$ & $\begin{array}{l}\text { Compresión } \\
\text { (Compresion) }\end{array}$ & & \\
\hline M-i-S & Control & - & 0.45 & 46.25 & 561.09 & 24 & 13 \\
\hline$M-L-T$ & Control & - & 0.45 & 84.00 & 521.72 & 23 & 11 \\
\hline$M-11-S$ & Cera M. & $2.5^{x}$ & 0.43 & 51.25 & 698.91 & 19 & 10 \\
\hline$M-I I-T$ & $\begin{array}{l}\text { Cera M. } \\
\text { (Montan wax) }\end{array}$ & $2.5^{x}$ & 0.43 & 99.00 & 610.31 & 20 & 10 \\
\hline M-III-S & Tanino & 0.2 & 0.36 & 47.50 & 413.44 & 19 & 11 \\
\hline$M-I I I-T$ & $\begin{array}{l}\text { Tanino } \\
\text { (Tannin) }\end{array}$ & 0.2 & 0.36 & 81.50 & 315.00 & 18 & 10 \\
\hline M-IV-S & Colofonia & 0.5 & 0.37 & 51.75 & 570.94 & 12 & 6 \\
\hline$M-I V-T$ & $\begin{array}{l}\text { Colofonia } \\
\text { (Colophony) }\end{array}$ & 0.5 & 0.37 & 42.00 & 433.13 & 10 & 5 \\
\hline M-V-S & $\begin{array}{l}\text { Cera M. } \\
\text { Colofonia }\end{array}$ & $\begin{array}{l}2.5^{x} \\
0.5\end{array}$ & 0.37 & 46.75 & 393.75 & 10 & 6 \\
\hline$M-V-T$ & $\begin{array}{l}\text { Cera M. } \\
\text { Colofonia }\end{array}$ & $2.5^{x}$ & 0.37 & 45.50 & 364.22 & 11 & 6 \\
\hline M-VI-S & $\begin{array}{l}\text { Tanino } \\
\text { Colofonia }\end{array}$ & $\begin{array}{l}0.1 \\
0.25\end{array}$ & 0.36 & 38.75 & 403.59 & 18 & 10 \\
\hline M-VI-T & $\begin{array}{l}\text { Tanino } \\
\text { Colofonia }\end{array}$ & $\begin{array}{l}0.1 \\
0.25\end{array}$ & 0.36 & 80.00 & 383.91 & 17 & 9 \\
\hline
\end{tabular}

(x) La adición es en \% sobre peso de mortero. (Addition is in \% of weight of mortar.

$S$ Sin tratamiento térmico. (Without heat treatment).

$T$ Con tratamiento térmico. (With heat treatment). 
Las otras tres probetas de cada serie no se sometieron a tratamiento térmico curándose en la cámara hasta la edad del ensayo.

La determinación de la porosidad relativa y la absorción de agua se realizó sumergiendo las probetas de $3 \times 40 \times 40 \mathrm{~mm}$ en agua durante 24 horas, de las que posteriormente se extraían secándolas a continuación en una estufa a $80^{\circ} \mathrm{C}$ durante 24 horas enfriándose después a temperatura ambiente. La edad a la que se han realizado los ensayos ha sido de 28 dias.

Los resultados obtenidos de las resistencias mecánicas, porosidad relativa y absorción de agua para las distintas mezclas estudiadas son los que se indican en los cuadros I y II.
The rest three cubes of each serie were not subjected to heat treatment they were only cured in the curing chamber up to the age of test.

In the determination of the relative porosity and water absorpcion the $3 \times 40 \times 40 \mathrm{~mm}$ cubes were submerged in water for 24 hours, latter they were taken from the water and followed by driying in the drying chamber at $80^{\circ} \mathrm{C}$ for 24 hours then cooled at ambient temperature. The test have been carried out at the age of 28 days.

The results obteined for mechanical resistence, relative porosity and water absorption for various mixed studied are indicated en tables I and II.

Cuadro II TABLE \|I

Mortero $1: 2$ (Mortar $1: 2$ )

\begin{tabular}{|c|c|c|c|c|c|c|c|}
\hline \multirow{2}{*}{$\begin{array}{l}\text { Identl- } \\
\text { ficación } \\
\text { (Identi- } \\
\text { fication) }\end{array}$} & \multirow{2}{*}{$\begin{array}{l}\text { Tipo de } \\
\text { adición } \\
\text { (Type of } \\
\text { addition) }\end{array}$} & \multirow{2}{*}{$\begin{array}{c}\text { Adición } \\
\% \\
\text { (Addi- } \\
\text { tion \%) }\end{array}$} & \multirow{2}{*}{$\begin{array}{c}\text { Relación } \\
\text { agua/ce- } \\
\text { mento } \\
\text { (Water/ } \\
\text { cement } \\
\text { ratio) }\end{array}$} & \multicolumn{2}{|c|}{$\begin{array}{c}\text { Resistencias mecánicas } \\
\text { (Mechanical resistences) } \\
\left.\text { (kgf/ } \mathbf{c m}^{2}\right)\end{array}$} & \multirow{2}{*}{$\begin{array}{c}\text { Porosidad } \\
\text { relativa } \\
\% \\
\text { (Relative } \\
\text { porosity } \\
\% \text { ) }\end{array}$} & \multirow{2}{*}{$\begin{array}{c}\text { Absorción } \\
\% \\
\text { (Absor- } \\
\text { tion \%) }\end{array}$} \\
\hline & & & & $\begin{array}{c}\text { Flexotracción } \\
\text { (Flexion) }\end{array}$ & $\begin{array}{l}\text { Compresión } \\
\text { (Compresion) }\end{array}$ & & \\
\hline M-I-S & Control & - & 0.45 & 45.75 & 482.34 & 28 & 12 \\
\hline$M-I-T$ & Control & - & 0.45 & 56.00 & 497.11 & 23 & 11 \\
\hline M-II-S & Cera M. & $2.5^{x}$ & 0.40 & 41.25 & 541.41 & 11 & 6 \\
\hline$M-H I-T$ & $\begin{array}{l}\text { Cera M. } \\
\text { (Montan wax) }\end{array}$ & $2.5^{x}$ & 0.40 & 41.25 & 450.84 & 12 & 6 \\
\hline M-III-S & Tanino & 0.4 & 0.37 & 53.25 & 624.09 & 7 & 3 \\
\hline$M-I I I-T$ & $\begin{array}{l}\text { Tanino } \\
\text { (Tannin) }\end{array}$ & 0.4 & 0.37 & 57.63 & 689.06 & 7 & 4 \\
\hline M-IV-S & Colofonia & 0.4 & 0.37 & 36.75 & 393.75 & 9 & 4 \\
\hline M-IV-T & $\begin{array}{l}\text { Colofonia } \\
\text { (Colophony) }\end{array}$ & 0.4 & 0.37 & 40.38 & 329.77 & 9 & 5 \\
\hline M-V-S & $\begin{array}{l}\text { Cera M. } \\
\text { Colofonia }\end{array}$ & $\begin{array}{l}2.5^{x} \\
0.4\end{array}$ & 0.37 & 32.00 & 295.31 & 10 & 5 \\
\hline$M-V-T$ & $\begin{array}{l}\text { Cera M. } \\
\text { Colofonia }\end{array}$ & $\begin{array}{l}2: 5^{x} \\
0.4\end{array}$ & 0.37 & 34.50 & 359.30 & 10 & 5 \\
\hline M-VI-S & $\begin{array}{l}\text { Tanino } \\
\text { Colofonia }\end{array}$ & $\begin{array}{l}0.2 \\
0.2\end{array}$ & 0.37 & 36.00 & 403.59 & 11 & 6 \\
\hline M-VI-T & $\begin{array}{l}\text { Tanino } \\
\text { Colofonia }\end{array}$ & $\begin{array}{l}0.2 \\
0.2\end{array}$ & 0.37 & 41.75 & 326.81 & 11 & 6 \\
\hline
\end{tabular}

(x) La adición es en \% sobre peso de mortero. (Addition is in \% of weight of mortar.

S Sin tratamiento tórmico. (Without heat: treatment).

$\mathrm{T}$ Con tratamiento térmico. (With heat treatment). 


\section{RESISTENCIAS MECÁNICAS}

Con estas adiciones se esperaba mejorar las resistencias mecánicas al disminuir el agua necesaria de amasado y forzar la hidratación del cemento; hay que tener en cuenta que las adiciones incorporadas son adsorbidas y orientadas en la superficie de los granos, produciendo un efecto lubricante y una dispersión de los granos de cemento que oueden mojarse con una cantidad de agua minima.

Los resultados del estudio para morteros : 1,5 y $1: 2$ figuran en los cuadros $\mid$ y 11 .

Según se deduce de los cuadros, el empleo de coiofonia en los morteros $1: 1,5$, sin tratamiento térmico, mejora las resistencias mecánicas a compresión y flexotracción, con respecto al mortero de control en un $2 \%$ y $12 \%$ respectivamente; sin embargo, el efecto es completamente opuesto, cuando los morteros se someten a tratamiento térmico.

Para los morteros 1:2 todos los resultados fueron inferiores a los de control, pero aquí hay que señalar que los porcentajes de adiciones no son similares a los de los morteros $1: 1,5$.

En los casos en los que se empleó cera montana como adición en los morteros $1: 1,5$ hubo un aumento de resistencias a flexión y combresión del $11 \%$ y $25 \%$ (sin tratamiento térmico) y del $18 \%$ y $17 \%$ (con tratamiento térmico) respectivamente; sin embargo para el tanino no fue así aunque los resultados fueron mejores que con colofonia.

Los morteros $1: 2$ con adición de tanino aumentaron las resistencias mecánicas en ambos casos (máximo $16 \%$ en flexión y $37 \%$ en compresión sin y con tratamientos térmicos respectivamente).

En los casos en los que se empleó mezcla de coló́onia con tanino o con cera montana no hubo ninguna mejora en las resistencias mecánicas.

\section{POROSIDAD RELATIVA}

Según se deduce de los cuadros I y II la colofonia disminuye notablemente la porosidad relativa de los morteros, tanto en los de composición $1: 1,5$ como en los de composición $1: 2$. Las reducciones son superiores al $50 \%$ y $60 \%$ respectivamente con respecto al mortero de control.

\section{MACHANICAL RESISTANCE}

With these additives, it was expected to improve the mechanical properties for the decrease of the necessary mising water and the forced cement hydration; it is necessary to note that the additives incorporated are ad sorbed and oriented to the grain surfaces, producings a lubricating effect and a dispersion of the cement grains which can be wetted by minimum water quantity.

Results of $1: 1.5$ and $1: 2$ mortar mixes appear on the tabies I and II.

From the tables it is observed that, the use of colophony in mix $1: 1.5$ without heat treatment improves the mechanical resistence to compression and flexural, compared with the control mix, by $2 \%$ and $12 \%$ respectively, however the effect is completely opposite when the mortars are subjected to heat treaiment.

For the mixes $1: 2$ all the results were lower than those for the control but here, it is better to note that percentage additions are not similar to the mixes of $1: 1.5$.

In those mixes where montan wax were used in mixes 1:1.5 there was an increase of resistence to flexion and compresion by $11 \%$ and $25 \%$ (without heat treatment) and by $18 \%$ and $17 \%$ (without heat treatment) respectively, but for the tannin this was not the case although the results were better than those with colophony.

The mortars of mix $1: 2$ with tannin addition increased their mechanical resistance in both cases (maximum $16 \%$ in flexural and $37 \%$ in compresion with or without heat treatment respectively).

\section{RELATIVE POROSITY}

From the tables I and II it is observed that the colophony reduces the relative porosity of the mortars in the mixes $1: 1.5$ as wellas $1: 2$.

The reduccion are higher than $50 \%$ and $60 \%$ respectively with respect of the control mortar. 
La adición de cera montana a la colofonia no modifica prácticamente los resultados obtenidos con respecto a ésta como única adición, en cualquiera de los dos morteros estudiados. Cuando se adiciona tanino junto con colofonia la disminución del porcentaje de poros es sensiblemente inferior al que se produce en colofonia sola en el caso del mortero $1: 1,5$ y se mantiene prácticamente igual en el mortero $1: 2$. En todo caso, se observa una disminución en el porcentaje de poros con respecto a los morteros de control.

\section{ABSORCIÓN}

De los cuadros I y II se desprende asimismo que la colofonia reduce de una forma importante el porcentaje de absorción de agua de los morteros ensayados. Hay que señalar también que la adición de cera montana o de tanino a la colofonia produce los mismos efectos que en el caso de la porosidad. Asimismo, los porcentajes de disminución de absorción de agua son de valores similares a los obtenidos en el caso de la porosidad.

\section{CONCLUSIONES}

El empleo de materiales aglutinantes poliméricos como aditivos para cemento portland no es nada nuevo, sí lo es el empleo de la colofonia en el mortero de cemento.

La colofonia posee características hidrofóbicas e hidrofílicas, que han contribuido favorablemente en las mejoras de las propiedades físicas, mecánicas y químicas del mortero de cemento; particularmente las referidas a resistencias a flexotracción, absorción y, por supuesto, porosidad.

La reducción del $\mathrm{pH}$ alcalino se ha comprobado añadiendo colofonia $(0,4 \mathrm{M})$ en disolución alcalina de hidróxidos de calcio o sodio con $\mathrm{pH} 12$, observándose que el $\mathrm{pH}$ se redujo a los valores de 6 - 5 y 9 respectivemente.

Esta reducción hace que el material sea apto para su empleo en compuestos reforzados con fibras sensibles a los álcalis del cemento.

Siendo éstos los primeros estudios que se realizan sobre esta adición, este artículo presenta unos resultados aceptables y que, por supuesto son susceptibles de mejorar, teniendo en cuenta que de acuerdo con las referencias bibliográficas, la efectividad de materiales poliméricos de adición, es mayor si el aditivo se añade en forma de disolución y el curado se efectúa al aire seco después del moldeo (8).
The montan wax admixtures to the colophony practically does not modify the results obtained with respect of the mixes which contained colophony only, in whichever case of mortar studied. When tannin and colophony, jointly are added, the reduccion of the percentage of pores is sensiblely inferior to the one produced by the addition of colophony only in the mix of $1: 1.5$ and it is maintained practically equal in the mix $1: 2$. It is observed as a whole a reduccion of percentages of pores when compared with the control mortar.

\section{ABSORPTION}

The table I and II shows that the colophony reduces the percentage of water obsroption of the mortar tested in a very important form. Also it is better to indicate that the addition of montan wax or tannin to colophony produces the same effects to those of the porosity. Similarly the percentage decrease of water absorption are of the same values to those obtained in the case of the porosity.

\section{CONCLUSIONS}

The use of aglutinate polymeric materials as admixtures in portland cement is nothing new; what is new is the use of colophony in the cement mortar.

The colophony has dydrofobic and hydrophylic characteristics which has favourably contributed to the improvement of the physical, mechanical and chemical properties of the cement mortar; particularly those refered to resistance to bending, absorption and of course porosity.

The reduction of the alkaline $\mathrm{pH}$ has been proved by adding colophony $(0.4 \mathrm{M})$ in an alkaline solution of calcium hydroxide or sodium hydroxide of $12 \mathrm{pH}$, observing that the $\mathrm{pH}$ values reduced to 6.5 and 9 respectively.

This reduction makes the material suitable for use in composites reinforced with fibres which are sensitive to cement alkalis.

These, being the first studies done on this admixtures, the article presents some acceptable results and of course they are susceptibles to improvement, having in mind that, following bibliografical refferences, the efectivity of polymerical materials as admixtures, is better if the admixture is added in a form of solution and the curing is done in open dry air after demolding (9). 


\section{BIBLIOGRAFIA}

(1) SAYRE, E. V.: Deterioration and Restoration of Plasters, Concrete and Mortar, Preservation and Conservation; Principles y Practices. Washingon, S. C. 1976 pp. S $91-20 \mathrm{~J}$.

(2) NENBERGER A.: Die Teknik des Aftertum R. Voigtländer Vertag in Leipzig East Germany 1931. Traducido por Henry L. B. Methuen; London 1930.

(3) BANKART G. P.: The art of Plasterer, B. T. Badford, London 1908.

(4) CHANDRA S.; AAVIK J.: Influence of Proteins on Some Properties of Portland Cement Mortar. The Inter. Journ. of Cement Composites and Lightweight Concrete Vol. 9 n. 2 May 1987 pp 91-94.

(5) LEHNINGER A. L. Bioquimica. Ed. Omega, S.A. 1981.

(6) RAMACHANDRAN, V. S.: Admixture and Addition Interactions in Cement-Water System. II Cemento Anno 83/GennaioMarzo 1986 N. 1 pp 13-37.

(7) THOMAS N. L.; BIRCHALL, J. D.: The Retarding Action of Sugars on Cement Hydration, Cement and Concrete Research Vol. 13 N. ${ }^{\circ} 5$, pp 830-842.

(8) BAYKOV, V. N.; SIGALOV E. E.: Estructuras de Hormigón Armado; Mir 1980 pp 46-47.

(9) NEVILLE, A. M.: Properties of Concrete; A. Pitman. International text 1977.

(10) KAYYALI, G. A.: Porosity of concrete in relation to the nature of paste aggregate interfase. Rilem Vol. 20 No 115 Jaunary 1987. Materials and Structures Research and testing pp. 19-26.

(11) CANOVAS, M. F. y SOTO, M. C.: Morteros y hormigones con cera: ¿una respuesta a la durabilidad? Materiales de Construcción n.॰178, Junio 1980.

(12) JENKINS G. H., et al. Internally Sealed Concrete. Monsanto Research Corporation, N.T.I.S. PB 243011 , Jaunary 1975.

(13) CHANDRA S.; AAVIK J.: Influence of Black Gram (Natural Organic Material) Addition as Admixtures in Cement Mortar and Concrete. Cement and Concrete Research. Vol. 13 pp. 423-430, 1983.

\section{publicaciones del ICCET/CSIC}

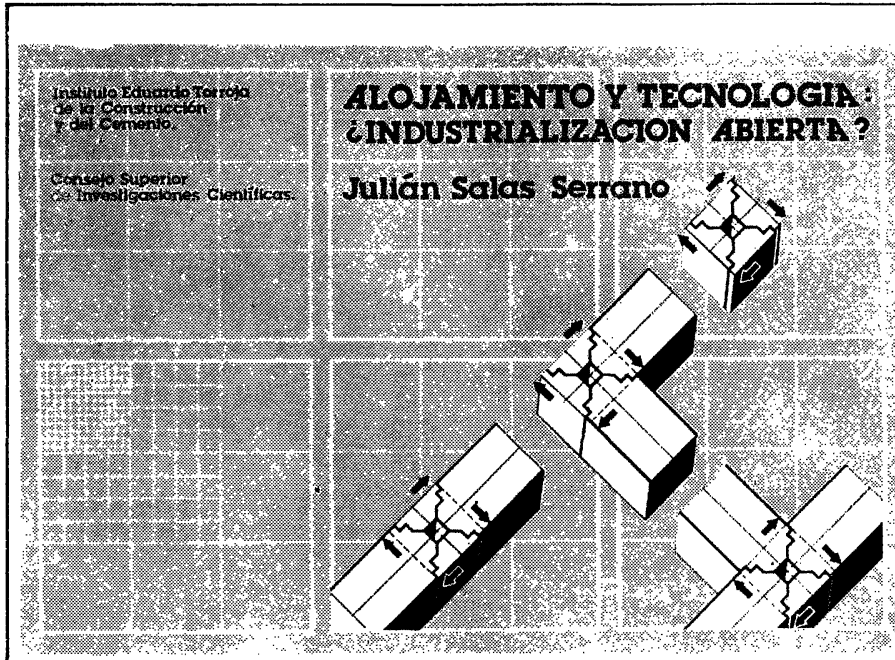

\section{ALOJAMIENTO Y TECNOLOGIA: ¿INDUSTRIALIZACION ABIERTA?}

JULIAN SALAS, ING. IND. (I.E.T.c.c.) Un volumen de 160 páginas, 109 figuras y 16 tablas. Tamaño $240 \times 168 \mathrm{~mm}$. Encuadernado en rústica. Precios: España, 1.200 ptas; extranjero, 17 \$ USA.

\section{SUMARIO:}

Prólogo Prof. G. Ciribini.

\section{Introducción}

Capitulo 1. - La industrialización en las proclamas y manifiestos de arquitectura.

Capitulo 2.-¿Réquiem por la construcción industrializada?

Capitulo 3.-Algunos conceptos básicos.

Capítulo 4.-¿Proyecto tradicional, construcción industrializada?

Capítulo 5.-Componentes.

Capítulo 6. - La coordinación dimensional hoy.

Capítulo 7.-Flexibilidad, intercambiabilidad y catálogos.

Capitulo 8. - Industrialización, normativa y calidad.

Capitulo 9.-Reflexiones finales.

\section{publicación del}

INSTITUTO EDUARDO TORROJA 